\title{
A Brief Answer: Why is China's Aquaculture Industry so Successful?
}

\author{
Samantha D. Farquhar (Corresponding author) \\ Asian Institute of Technology, Aqua-Centre, Bangkok, Thailand \\ Agriculture and Forestry University, Department of Aquaculture and Fisheries, Rampur, Nepal \\ E-mail: farquharsamantha6@gmail.com
}

Sebastian M. Sims

University of Southampton, National Oceanography Centre, Southampton, England

Shu-Jiao Wang \& Kiera S. Morrill

Received: March 2, 2017 Accepted: April 15, 2017

doi:10.5296/emsd.v6i1.11108 URL: https://doi.org/10.5296/emsd.v6i1.11108

\begin{abstract}
As wild capture fisheries continue to be exhausted worldwide, aquaculture is being looked as the sustainable solution to meet the global fisheries demand. China is one of the most successful countries in the world when it comes to aquaculture. They produce more fish than they catch, simultaneously providing for their own country and the rest of the world. By contrast, the United States imports over $90 \%$ of its fisheries; its aquaculture industry meeting only $5 \%$ of the country's total demand of fish. While the United States prides itself on being a world leader in several fronts, aquaculture is certainly not one of them. This makes anyone question: why is China's aquaculture so successful? This manuscript works to answer this question briefly by identifying and exploring three notable characteristics of China's aquaculture industry: (1) history; (2) size and diversity; and (3) government support and research. It goes on to suggest how the U.S. can improve it aquaculture industry based on the Chinese success story.
\end{abstract}

Keywords: Fish farming, Environmental history, Environmental policy

\section{Introduction}

With the world's population increasing exponentially, the demand of fisheries has been the 
highest ever in history. In 2014, the global total for fisheries production was 167.2 million tons (FAO, 2016). This demand is showing no signs of slowing. The Food and Agriculture Organization of the United Nations (FAO) expects an additional 27 million tons of production will be needed to maintain the present level of per capita fisheries consumption of 20 kilograms or 44 pounds per year in 2030 (FAO, 2016). As the majority of capture fisheries are becoming overexploited and collapsing, concerns are growing for the future food security of the world as it is estimated that fisheries account for $17 \%$ of the global population's intake of protein (FAO, 2016). Aquaculture (the breeding, rearing, and harvesting of aquatic plants and animals), has been regarded as the solution to this problem. Compared to land based protein, aquaculture offers a more resource-efficient means of producing protein as it takes less feed and space. Aquaculture also allows for a more regulated and controlled means of food production and acquisition (White, O’Niell, \& Tzankova, 2004).

In 2014, aquaculture accounted for $45 \%$ or 73.8 million tons of the global fisheries production. The majority of this, 58,795,300 tons, was supplied by China with a worth of $\$ 138$ billion dollars (FAO, 2016). China is unarguably the most successful country in the world when it comes to aquaculture. They are one of the few countries that farm more fish than they catch, providing $80 \%$ of the fish products that their own country consumes. Furthermore, it is estimated that in 2020, Chinese aquaculture will make up $61 \%$ of the world production.

By contrast, the United States aquaculture industry only meets 5-7\% of the country's demand for fisheries (NASS, 2014). Instead, the United States is the lead importer of fisheries products; over 20\% are bought from China (FAO, 2016). While the United States prides itself on being a world leader in several fronts, aquaculture is certainly not one of them. This brings us to the question: why is China's aquaculture so successful? This manuscript identifies and explores three notable characteristics of China's successful aquaculture industry (1) history; (2) size and diversity; and (3) government support and research.

\section{History}

\subsection{China Has Much More Experience with Aquaculture Than the US.}

China was cultivating fishes as early as 11th century B.C. with common carp (Cyprinus carpio), being raised in freshwater ponds (Li et al., 2011; Liao, 2000; Zhao \& Shen, 2016). The Chinese scholar, Fan Li in his work, "Fan Li on Pisciculture" in 5th century B.C, first documented this. During the Tang dynasty (618-917 AD), the cultured species then expanded to silver carp (Hypophthalmichthys molitrix), big-head carp (Aristichthys nobilis), grass carp (Ctenopharyngodon idellus), black carp (Mylopharyngodon piceus) and mud carp (Cirrhina molitorella) (Liao, 2000). Seeds (referring to eggs, fry, or larvae) from the majority of these species were collected from the Yangtze River and transferred into the ponds for growing. Later in the Song dynasty (960-1279 AD), farmers began catching fingerlings (juvenile fish) of these species from the wild and successfully transported them to distant areas for farming. Additionally, oyster farming was recorded as early as the Han dynasty (206 BC to 220 AD). Research was even being conducted in these early days. In the Ming dynasty, Xu Guangqi (1639 AD) recorded the methods of freshwater fish farming and prevention of fish diseases 
(FAO Fisheries and Aquaculture Department, 2011; Liao, 2000). Traditionally, fish farming in China was family based, on a small-scale, and used to support the household. The expansion of the farming slowed drastically in the early 20th century with various political conflicts and scarcity of fish seed due to high demand. However, the boom in aquaculture can be seen with the transition to the market-driven economy in the late 1970s (Liao, 2000). During this period, technological and scientific advancement were heavily sponsored by the central government and ultimately paved the way for the industry's large-scale production seen today (Cao et al., 2015; X. Li et al., 2011a). The industry continued to expand and began including mollusks, crustaceans, and seaweed after the 1980s. Ultimately, the Chinese government catalyzed the expansion of aquaculture by taking advantage of the country's rich history and experience. The success of this involvement can be seen in the staggering numbers. In 1950, China produced 75,961 tons of fisheries by aquaculture and now, just over 65 years later, they are the world leader producing over 58,797,258 tons (FAO, 2016).

2.2. Conversely, the United States is very new to aquaculture and can officially trace its roots back to the 1870s when the US Commission for Fish and Fisheries was created (FAO Fisheries and Aquaculture Department, 2016; Knapp \& Rubino, 2016). Unlike China, where families traditionally started the farming, the federal and state agencies initiated the farming through their implementation of fish hatcheries. These hatcheries worked to produce fish seed, which was then used to stock local water bodies. The hatcheries in the 1880s focused heavily on trout and catfish (FAO Fisheries and Aquaculture Department, 2016). As time passed, the commission stocked lakes, farm ponds, rivers, reservoirs, and streams. Eventually other species were included such as salmon, tilapia, oysters, and crawfish. As aquaculture spread, private businesses began getting involved and number of farmer cooperatives formed (FAO Fisheries and Aquaculture Department, 2016; Knapp \& Rubino, 2016). Like China, the aquaculture industry didn't rapidly expand until the 1980's. This was shortly after the United States passed the National Aquaculture Act of 1980 to promote, support, and regulate the development of private aquaculture.

\section{Size and Diversity}

\subsection{China's Aquaculture Industry Has Much More Farmers and It Rears a Broader Range of Species than the US.}

China's aquaculture industry employs over 6 million people throughout the country (FAO, 2016). Furthermore, the Chinese aquaculture industry comprises over 150 different species allowing for a wide-range of products to be sold to multiple markets. This includes fishes, mollusks, crustaceans, seaweeds, and invertebrates (China Agriculture Yearbook Editorial Board, 2011). Some of the most popular species are: tilapia, shrimp, bream, catfish, scallops, carp, oysters, and mussels. The methods of farming as well have diversified to embrace polyculture systems, integrated farming systems, and intensive culture systems (Cao et al., 2015; Li et al., 2011). Extensive aquaculture is also used, primarily for the cultivation of macroalgae.

3.2. Polyculture is a farming technique that has particularly contributed to the success of Chinese aquaculture over the years. It works on the principle that the different species that are 
farmed function at differing feeding functional groups and trophic levels, leading to a greater efficiency in food production. Typically, this has consisted of the polyculture of several carp species in fresh water ponds. However, there have recently been several changes in the management of these aquaculture ponds, in order to reduce environmental damage. Polyculture has been used to improve the water quality of what were previously intensive monoculture systems. For example, adding shrimp to a sea cucumber pond has the effect of reducing the amount of suspended organic matter, and suspended particulate organic matter present in the water column (Yu et al., 2016). As well as polyculture of certain species, the rotation of species cultivated can be used to reduce the environmental impact. Rotating carp polyculture with mitten crabs reduces the amount of nitrogen and phosphorous loading, reducing the risk of eutrophication in the Hongze Lake region (Wang et al., 2016).

3.3. China's aquaculture industry is concentrated largely in the coastal regions, with the regions of Guangdong, Shandong, Fujian, Jiangsu and Hubei being the key aquaculture provinces in China. Individual farmers or private corporations own most of the farms. Because of this, it is hard to gauge exactly how many different farms China has, but the growth can be seen in total aquaculture area. In 1978, China reported 2.86 million hectares being used for aquaculture. In 2011, China's Agriculture Yearbook (CAY) reported that total aquaculture area was 7.83 million hectares.

3.4. Despite the United States having similar land area and technology, the aquaculture industry is minute in comparison. This is not because the United States lacks the resources or expertise. In fact, FAO has deemed the United States to have great potential for a strong aquaculture industry due to the country's long coastline, large marine Exclusive Economic Zone, skilled labor, improved technology and feeds, stable political system, and a large demand for fisheries (Knapp \& Rubino, 2016). Growth of the industry has largely been slowed by interest groups who raise concerns over water rights and have a negative perception of the quality of farmed fisheries (Chu, Anderson, Asche, \& Tudur, 2010; Knapp $\&$ Rubino, 2016). Additionally, leasing and other policies for aquaculture vary from state to state making the start-up process for fish farming sometimes difficult and cumbersome (Knapp \& Rubino, 2016). The United States 2013 Census of Aquaculture reported 3,093 farms in the country (NASS, 2014). These farms are spread across all 50 states, but Maine, Washington, Virginia, Louisiana, Mississippi and Idaho are the top producers. Shellfish such as oysters, clams, mussels, and scallops are more commonly grown than fishes, making up two-thirds of the total marine production. Other species grown are catfish, striped bass, tilapia, trout, crawfish, salmon, clams, mussels, oysters, and shrimp. Overall, approximately 60 species are farmed in the United States. Compared to China, this is significantly less. While the U.S. aquaculture is continuing to grow, it is doing so at a rather slow rate of $0.3 \%$ (FAO, 2016). Employment generation was estimated at 39,471 in 2007, an 18 percent increase from 33,384 jobs in 1998. However from 2007 to 2014, the sector declined by $19 \%$ in regards to production which decreased from 526,045 tons in 2007 to 425,870 tons in 2014. If production is proportional to jobs, the number of jobs in 2014 would be approximately 33,000 jobs (FAO Fisheries and Aquaculture Department, 2016). 


\section{Government Support and Research}

\subsection{China's Government Provides More Support to Developing the Aquaculture Industry as Compared to the US.}

China has a one-party political system where the ruling party sets out the path for economic and social developments in 'five-year plans'. Fisheries and aquaculture development can be seen to have a strong focus in these plans and are implemented on national, provincial and county level (Li et al., 2011; Zhao \& Shen, 2016). The Bureau of Fisheries under the Ministry of Agriculture is the main administrative department that oversees these plans after they are set forth by the central government. They also supervise fishery laws, and international or bilateral fisheries agreements with the objective to strengthen fisheries management and to ensure that the resources will be appropriately utilized. The Bureau of Fisheries also supports fisheries education, scientific research, and management of the fish processing industry. Under the Bureau of Fisheries, on the local level are Department of Fisheries offices found throughout the country in provinces, autonomous regions, municipalities and the county government. These offices work to implement the objectives of the plan as advised by the Bureau (FAO Fisheries and Aquaculture Department, 2011; X. Li et al., 2011b). These central and local governments also manage the National Fisheries Technology Extension Center. This is a vast network of sites that provide aquaculture support and training for farmers. In 2002, there were a reported 18,462 fisheries extension stations throughout China and it was reported that 1.8 million local farmers or extension workers have been trained through this network (Li et al., 2011).

4.2. China also has a vast research and education network sponsored by the central government. This is known as the Chinese Academy of Fishery Sciences, which is comprised of ten different research institutes. These institutes also work closely with universities and a number of private research institutes (FAO Fisheries and Aquaculture Department, 2011; Li, 2000). Education in aquaculture is a popular course of study; more than 30 Chinese universities enroll about 1,000 aquaculture students each year (FAO Fisheries and Aquaculture Department, 2011). Many of these universities offer upper level graduate degrees in aquaculture or closely related disciplines. The research from these institutes is then shared openly with the Extension Centers so that the information is effectively disseminated to the local farmers.

4.3. Similarly, the U.S. government is involved in the aquaculture industry through its state and federal organizations. The lead agency for freshwater aquaculture in the United States is the Department of Agriculture (USDA). The lead agency for marine aquaculture is the National Marine Fisheries Service (NMFS), which is part of the National Oceanic and Atmospheric Administration (NOAA) under the Department of Commerce (DOC). These organizations set policies for the country's aquaculture and establish goals for future production. Similar to China, they have ten-year plans that encompass these objectives (FAO Fisheries and Aquaculture Department, 2016). Despite, the goals and objectives of such plans, the U.S. aquaculture industry has not thrived like China. The number of fish farms has, in fact, decreased in recent years (NASS, 2014). As mentioned before, this has been attributed to the 
complex regulatory framework that varies from state to state. This includes the processes and policies involved in obtaining and maintaining leases for farms as well as resistance from riparian land owners (Knapp \& Rubino, 2016).

4.4. The U.S. government does not facilitate or implement these goals with the same vigor as China. Rather, they offer federal grants, loans, and aid in which farmers can apply for further developing the industry. NOAA's most recent ten-year plan for marine aquaculture outlined that, with the proper measures, by 2025 American aquaculture production could more than double, adding one million tons of production and creating 75,000 new jobs (NOAA NMFS, 2007). Like China, this plan includes innovative research, much of which happens at the university level. Research also takes place at 5 regional USDA Aquaculture Centers and 31 National Marine Fisheries Service research laboratories. However, private industries contribute to a large part of the U.S. industry as they are often affiliated with specific species and collaborate with government organizations in areas of mutual interest. These privately run farms have advanced the industry by developing voluntary environmental codes of conduct and best management practices to improve industry performance (FAO Fisheries and Aquaculture Department, 2016). The U.S. also has extension centers for aquaculture outreach and development. This is done through the USDA Cooperative Extension Service and comprises 74 locations throughout the country and its territories.

\section{Conclusion}

The success and size of the Chinese aquaculture industry can be contributed to its interconnectedness of its history, central government, diversity of species and research. Aquacululture in China has grown from a mainly artisanal industry in the form of several small polyculture ponds, to a large industry with a diverse mixture of production methods. Aquaculture in China continues to grow, and research is largely focused on reducing the environmental impacts of aquaculture. The United States currently imports a large proportion of the fish eaten in the country. Aquaculture offers a solution to drastically reduce the amount of imported fisheries to the U.S. Additionally, development of aquaculture in the U.S. can increase economic productivity through the addition of jobs and the mitigation of the $\$ 12.6$ billion fisheries trade deficit. In order to increase the aquaculture industry, the United States will ultimately need to make its industry more accessible through policy changes and outreach. More aquaculture legislation should be introduced, with targeted goals, and this should be done by central government in order to reduce the differences between the states. It should also encourage the cultivation of more species and education in aquaculture degree programs, including aquaculture, fish health and engineering. The USA could also focus on high-tech engineering solutions to the issues affecting aquaculture, including closed systems - which could be used to counter diseases, including salmon lice. The practice of aquaculture will be essential to future of world food security as wild capture fisheries continue to be exhausted and the world population continues to grow. Regardless of the country, proactively planning for these pressures by developing a strong sustainable aquaculture industry will prove valuable. 
Table 1. Summary of main differences in aquaculture industries between United States and China

\begin{tabular}{|l|l|l|}
\hline & China & United States \\
\hline Date of beginnings in aquaculture & 1100 B.C. & 1871 \\
\hline 2014 Aquaculture production (tons) & $58,795,300$ & 296,265 \\
\hline 2014 Revenue from aquaculture(USD) & $66,212,555,000$ & $1,005,658,000$ \\
\hline 2014 Number of commercially valuable species farmed & $\sim 150$ & $\sim 60$ \\
\hline 2014 Employment by aquaculture & $6,000,000$ & 33,000 \\
\hline
\end{tabular}

\section{References}

Cao, L., Naylor, R., Henriksson, P., Leadbitter, D., Metian, M., Troell, M., \& Zhang, W. (2015). China's aquaculture and the world's wild fisheries. Science, 347(6218), 133-135. https://doi.org/10.1126/science.1260149

China Agriculture Yearbook Editorial Board. (2011). China Agriculture Yearbook. Retrieved from http://english.agri.gov.cn/service/ayb/201511/P020151104554814851102.pdf

Chu, J., Anderson, J. L., Asche, F., \& Tudur, L. (2010). Stakeholders' Perceptions of Aquaculture and Implications for its Future: A Comparison of the U.S.A. and Norway. Marine Resource Economics, 25(1), 61-76. https://doi.org/10.5950/0738-1360-25.1.61

FAO. (2016). The State of World Fisheries and Aquaculture 2016. Contributing to food security and nutrition for all., 200. https://doi.org/92-5-105177-1

FAO Fisheries and Aquaculture Department. (2011). FAO Fisheries \& Aquaculture - National Aquaculture Sector Overview - China. National Aquaculture Sector Overview Fact Sheets. Retrieved from http://www.fao.org/fishery/countrysector/naso_china/zh

FAO Fisheries and Aquaculture Department. (2016). National Aquaculture Sector Overview: United States of America. FAO, 1-16.

https://doi.org/http://www.fao.org/fishery/countrysector/naso_tanzania/en

Knapp, G., \& Rubino, M. C. (2016). The Political Economics of Marine Aquaculture in the United States. Reviews in Fisheries Science \& Aquaculture, 24(3), 213-229.

https://doi.org/10.1080/23308249.2015.1121202

Li, X., Li, J., Wang, Y., Fu, L., Fu, Y., Li, B., \& Jiao, B. (2011a). Aquaculture Industry in China: Current State, Challenges, and Outlook. Reviews in Fisheries Science, 19(3), 187-200. https://doi.org/10.1080/10641262.2011.573597

Liao IC. (2000). The state of finfish diversification in Asian aquaculture. Zaragoza: CIHEAM Cahiers Options Méditerranéennes, 109-125. Retrieved from http://om.ciheam.org/article.php?IDPDF=600610http://www.ciheam.org/

National Agricultural StatisticsService (NASS). (2014). 2013 Census of Aquaculture. United States Department of Agriculture, 3. Retrieved from 
https://www.agcensus.usda.gov/Publications/2012/Online_Resources/Aquaculture/Aqua.pdf

NOAA NMFS. (2007). NOAA 10-year plan for marine aquaculture. Retrieved from http://purl.fdlp.gov/GPO/gpo686

White, K., O’Niell, B., \& Tzankova, Z. (2004). At a Crossroads : Will Aquaculture Fulfill the Promise of the Blue Revolution? A SeaWeb Aquaculture Clearinghouse Report, 17. Retrieved from www.AquacultureClearinghouse.org

Wang, Q., Li, Z., Lian, Y., Du, X., Zhang, S., Yuan, J., \& De Silva, S. S. (2016). Farming system transformation yields significant reduction in nutrient loading: Case study of Hongze Lake, Yangtze River Basin, China. Aquaculture, 457, 109-117.

https://doi.org/10.1016/j.aquaculture.2016.02.025

Yu, H., Gao, Q., Dong, S., Sun, Y., \& Wang, F. (2016). Effect of co-culture of Chinese shrimp (Fenneropenaeus chinensis) and sea cucumber (Apostichopus japonicus Selenka) on pond environment. Journal of Ocean University of China, 15(5), 905-910.

https://10.1007/s11802-016-3014-9

Zhao, W., \& Shen, H. (2016). A statistical analysis of China's fisheries in the 12th five-year period. Aquaculture and Fisheries, 1, 41-49. https://doi.org/10.1016/j.aaf.2016.11.001

\section{Copyright Disclaimer}

Copyright for this article is retained by the author(s), with first publication rights granted to the journal.

This is an open-access article distributed under the terms and conditions of the Creative Commons Attribution license (http://creativecommons.org/licenses/by/3.0/). 